\title{
The Fourth Industrial Revolution: A New Ideology
}

\author{
Ian Moll
}

University of the Witwatersrand, Johannesburg, South Africa, lan.moll@wits.ac.za

\begin{abstract}
The hegemonic construal of the 'Fourth Industrial Revolution' portrays rapid technological developments as a bold, new industrial revolution. Since there is sparse evidence of any such revolution across the totality of social, political, cultural and economic institutions, locally and globally, the focus must turn to how this ideological frame functions to further the interests of social and economic elites worldwide. This article examines the way that Klaus Schwab, as the principal intellectual of the World Economic Forum and the interests it represents, has formulated and disseminated this ideology. The article argues that the 'Fourth Industrial Revolution' frame bolsters the contingent neoliberalism of the post-Washington consensus period, and therefore serves to obscure the continuing decline of the globalised world order with a 'brave new world' narrative.
\end{abstract}

Keywords: hegemony, ideology, Industrial Revolution, information technology, ICTs, neoliberalism, technological rationality, World Economic Forum

\section{Introduction}

The idea of the Fourth Industrial Revolution (4IR) currently seems hegemonic. Intellectuals, corporate leaders, politicians, educationists, and ordinary people across the spectrum - from conservatives to progressives - tend to operate as if its existence just is the case. There are debates about it, but few question that there is a 4IR. However, I have demonstrated elsewhere that there is no such phenomenon (Moll 2021a). There is simply no evidence of a contemporary, grand confluence of digital technologies that is radically transforming work, society and global power beyond the defining characteristics of the Third Industrial Revolution (3IR). Yet the ideologues of the 4IR hold sway. The context of belief in the 4IR shapes the practices and identities of billions in the interests of global economic and political elites, who are threatened by the fact that the digitalised, information-driven, international order is in trouble:

Portraying rapid technological development as a bold, new industrial revolution is a far stronger ideological strategy for those seeking to mobilise political, social and economic forces to secure their position of dominance against these threats than a whimpered appeal that we revive and repair the Third Industrial Revolution in which we actually continue to live. (Moll 2021a, 30)

This article develops this argument by examining how 4IR ideology works in our society. It does not suggest that we do not live in an era of accelerating information technology development. Rather, it contends that to construe this as a 'fourth industrial revolution' has little veracity.

\section{The Hegemony of Ideological Frames}

Ideology is a loosely coherent, mostly tacit belief system that functions, epistemically and practically, to motivate our actions and inactions. It is a framework of "worldviews, narratives, values, and norms that justify, challenge, and/or interpret a given social and 
political order, often by invoking an ideal vision of the social world" (Neubauer 2011, 213). 'Ideology' thus has a positive sense, denoting the dominant existential frame within which we understand and act upon reality. It also has a critical sense, dating back to Gramsci, referring to the manner in which social, economic, political and legal institutions naturalise this framework of belief, rendering it opaque as ideology.

Althusser advances three theses regarding ideology:

I. "Ideology has a material existence" $(1971,112)$.

II. "Ideology represents the imaginary relationship of individuals to their real conditions of existence" $(1971,109)$.

III. Therefore, our existence in ideology - Althusser uses the term "interpellation" consists in both a "real" relation and an "imaginary", lived relation (Althusser 1969, 233).

The first confirms that ideology always exists in the material practices of a social apparatus - conventional behaviour, language usage, habits and rituals. It is enacted 'know-how' that reproduces everyday life as common sense. The second thesis recognises that these lived relations function as systematic misrepresentations in social consciousness, in particular of the oppression of subordinate classes. The third thesis comprehends the instantiation in human beings of these ideological practices and impulses (although Althusser, from within his "theoretical anti-humanism", would not phrase it in these terms - an issue that I do not intend to pursue further here). In all these insights, Althusser's work is foundational in the study of ideology.

Nonetheless, Althusser has been variously criticised for denying the possibility of resistance and struggle against hegemonic ideology (e.g. Thompson 1978; Hall 1980; Soper 1986). His view is a pessimistic political account of Gramsci, in which the reproductive functions of ideological state apparatuses predominate over emancipatory action. He says, for instance, that activists who "attempt to turn the few weapons they can find [...] against the ideology, the system and the practices [...] do not even begin to suspect [...that] the system is bigger than they are and crushes them" $(1971,157)$. The theorists I work with here no doubt have too much of a humanist bent for Althusser, but they do illuminate further the three theses above regarding the contemporary information technology order.

The cognitive scientists Lakoff and Johnson (1980; 1999) study the cognitive constitution of ideology by frames - metaphors, symbolic representations and cognitive heuristics that together constitute the "common sense" (1999, 23 et passim) of a dominant political and socio-economic system. Their neurolinguistic research demonstrates that these embodied frames activate particular mental schemas, which condition our reasoning and perceptions about any issue. Our politics and morality become physically constituted in our brains, where neural binding turns them into the "executing schemas" of the mind. Such frames are activated "unconsciously, automatically, as a matter of reflex" (Lakoff 2008, 34) - hence their ideological function. In Metaphors We Live By, Lakoff and Johnson (1980) suggest that frames influence every aspect of our lives profoundly - we cannot not think metaphorically.

Lakoff and Johnson have affinities with early 20th-century Marxists such as Gramsci, Adorno, Horkheimer and Marcuse, who analysed how ideology works at the social level to obscure from people the real conditions of their own lives.

Gramsci elaborates the classical Marxist view of ideology, specifically that class conflict inherent in economic relations of production directly determines "the legal, po- 
litical, religious, artistic or philosophic - in short, ideological forms in which men become conscious of this conflict and fight it out" (Marx 1859/1977). However, Gramsci's notion of hegemony transcends this economic reductionism. Hegemony appears as the political or cultural dominance of one group of people over another, based primarily on the consent of the dominated. It operates by the creation and reproduction of a weltanschauung- a world view that produces "moral and political passivity" (Gramsci 1971, 333). "Traditional intellectuals" work unwittingly - regarding themselves as autonomous - and "organic intellectuals" of the ruling bloc work deliberately, to maintain this weltanschauung (Gramsci 1971, 3-6; Salamini 1974, 366-368). Where Lakoff and Johnson talk of the prevailing "common sense" that orders our everyday, mundane understanding of the world in psychological terms, Gramsci talks of it in social terms.

Collectively, the Frankfurt School (including Adorno, Horkheimer and Marcuse) reveals "technological rationality" as the ideology of domination in advanced industrial societies. Although this notion was developed in the middle of the last century, it is still widely used to analyse contemporary, digitalised capitalism. Zuboff (2019), in her ground-breaking account of surveillance capitalism, shows how the predictive algorithms of machine intelligence monitor and deliver the workers, consumers and citizens required by the economic and political order. Delanty and Harris $(2021,91)$ describe this process as "modern technological rationality". Similarly, Bilić (2018) examines the growth of Google as an instance of the "technological rationality of algorithmic capitalism"; and Benyera (2021, 69-70) explores the role of technology companies in "alienating Africans from their data [...] data miners and harvesters become the embodiment of technological rationality" and the new colonisers of Africa.

Just as it did in the "culture industry" of pre- and post-war Europe, technological rationality fashions everyday life into a "a world of instrumentalities" that regulate our beliefs, experiences and thoughts (Marcuse 1964, 18). The ensemble of media forms such as film, radio and newspapers (today, we add television and social media, the most pervasive media forms ever) "enframes" ideological representations of the world: "the basis on which technology is gaining power over society is the power of those whose economic position in society is strongest. Technical rationality today is the rationality of domination" (Horkheimer and Adorno 1944/2002, 95, my emphasis). Myths such as the 4IR become instantiated socially and psychologically as an ideological frame that functions hegemonically.

\section{The Frame of the 'Fourth Industrial Revolution'}

Klaus Schwab (2016) famously intervened in global discourse about the digitalised information economy by introducing the notion of the 4IR at the World Economic Forum (WEF) in Davos in January 2016. Of course, many of his ideas were not his own. Industrie 4.0, a 2011 strategic initiative of the German government to increase digitisation in manufacturing (Fuchs 2018; Reischauer 2018), was an obvious influence. Fuchs (2018) calls it the "Digital German Ideology", which will delight those old enough to spot the allusion! By 2015, the World Summit on Technological Unemployment was debating "disruptive technologies that will allegedly create jobless growth and worldwide unemployment [...owing to] robotics, artificial intelligence, 3D-printing, and other innovations with enormous disruptive potential" (Peters 2017, 1).

However, Schwab pulled off a remarkable ideological coup with a cluster of metaphors narrating the imagined revolution. Gillwald (2019) calls it "one of the most successful lobbying and policy influence instruments of our time". This frame is now well established. It is largely tacit, but let me try to make it explicit. It operates as a formula: 
I. List between 7 and 15 technologies, mostly digital, that sound smart, make us feel outdated, and leave us in awe of the future. Even if they are not twenty-first century innovations, declare them so.

II. Declare that there is amazing, unprecedented convergence between these technologies.

III. Suggest that they produce changes that will disrupt and transform every part of our lives.

IV. Appeal to each of the previous industrial revolutions as an exemplar of the current one.

V. Name one or two core technologies or energy sources in the previous industrial revolutions. Proven suggestions are the steam engine for the 1IR; the internal combustion engine and/or electricity for the 2IR; computers and/or nuclear energy for the 3IR (you would have mentioned the Internet in point 1 , so avoid that here).

Schwab himself establishes the standard:

The 4IR is unlike anything humankind has experienced before. [...T]hink about the staggering confluence of emerging technology breakthroughs, covering wide-ranging fields such as artificial intelligence, robotics, the internet of things, autonomous vehicles, 3D printing, nanotechnology, biotechnology, materials science, energy storage and quantum computing [...] they build on and amplify each other in a fusion of technologies across the physical, digital and biological worlds [...] The first industrial revolution [...was t]riggered by the construction of railroads and the invention of the steam engine [...] The second industrial revolution [...] made mass production possible, fostered by the advent of electricity and the assembly line. The third industrial revolution began in the 1960s. It is usually called the computer or digital revolution because it was catalysed by the development of semiconductors, mainframe computing, personal computing and the internet [...] I am convinced that the 4IR will be as powerful, impactful and historically important as the previous three" $(2016,7 ; 11 ; 13$, my emphases).

Other ideologues of the 4IR replicate the message closely:

- "The 'fourth industrial revolution' captures the idea of the confluence of new technologies and their cumulative impact on our world. Artificial intelligence can produce a medical diagnosis [...] Robots can manufacture cars faster and with more precision [...] Autonomous vehicles will change traffic flows [...] The first industrial revolution spanned 1760 to 1840 , epitomised by the steam engine. The second started in the late 19th century and made mass production possible. The third began in the 1960s with mainframe computing and semi-conductors. The argument for a [fourth] category [...] is compelling. New technologies are developing with exponential velocity, breadth and depth" (Harvey 2017).

- "The first three industrial revolutions were characterised by technological advancements but not at the rate of current times. [...] This new revolution is about breaking frontiers. [...it is] characterized by a much more ubiquitous and mobile internet, by smaller and more powerful sensors [...] and by artificial intelligence 
and machine learning [...it] includes gene sequencing, nanotechnology, renewables, and quantum computing. [...] It is the fusion of these technologies and their interaction across the physical, digital, and biological domains that make the 4IR fundamentally different from the previous revolutions" (Kayembe and Nel 2019, 81-82).

The number of relays of this kind in the message chain goes on and on. The ideology of the 4IR is apparently hegemonic.

\section{The Establishment of the 'Fourth Industrial Revolution' as Ideology}

The annual WEF excursion to Davos brings together global economic elites: corporate heavyweights, heads of state, global intellectuals, and their entourages. The WEF styles it as networking "for a more inclusive, cohesive and sustainable future" (WEF 2021). The cohesion that it seeks is, of course, ideological cohesion. In 2016, it was triumphant. World leaders returned home with a formula that seems to convince their subjects, constituents, customers or clients that we are on the brink of a brand new order. From then onwards, the notion that a 4IR is upon us has become hegemonic in social, political and economic discourse around the world.

Schwab (2016) taps successfully into our internalised technological rationality. He proclaims the unprecedented speed, size and scope of the 4IR. The velocity of change, he says, is exponential rather than linear; the combining of multiple technologies is broader and deeper than ever before; and the systems impact is now total, across the whole of society and the global economy (2016, 8-9). Thus, he asserts, "disruption and innovation [...] is faster than ever" (14). Simultaneously, Schwab dismisses much of our expertise on this matter: "I am well aware that some academics and professionals consider the developments that I am looking at as simply a part of the third industrial revolution" (8).

Consider some of the expertise that he ignores. First, the contribution of Manuel Castells, the Spanish sociologist acknowledged as the primary theorist of the network society that emerged in the seventies - the "society whose social structure is made up of networks powered by micro-electronics-based information and communications technologies" (Castells 2004, 3). Castells (2000) shows that by the nineties the entire world was organised around networked information systems. However, the critical role of networked information and communication technologies (ICTs) is a "double-edged sword" (Castells 1999, 3): some countries accelerate economic growth by introducing digital economic systems, but those unable to do so become increasingly marginalised; "Their retardation becomes cumulative" $(1999,3)$. Castells writes extensively about what he terms "the other side of the information age: inequality poverty, misery and social exclusion" $(1999,7)$, all of which are currently the growing legacy of the globalised information economy.

Evidently, Schwab has been influenced by Castells. Yet he cites Castells only once (Schwab 2016, 86). Schwab's problem is that Castells does not deal in the ideological currency of 'industrial revolutions'. The latter's empirical research does not evidence a fundamental digital transformation of society in the contemporary era.

Another expert whom Schwab ignores is Jeremy Rifkin. By 2016, when the former proposed his notion of the 4IR, Rifkin $(1995 ; 2011$; 2014) had been writing for some time on workplaces in which robotics had taken over strategic and managerial functions in economic production. There is a notable disagreement between them. Rifkin does not think that these dramatic changes associated with ICTs constitute a 4IR. 
In 2016, Rifkin argued that the WEF had "misfired" with its 4IR intervention. He challenged Schwab's claim that the fusion of physical systems, biological processes and digital technologies was a qualitatively new phenomenon:

The very nature of digitalization [...] is its ability to reduce communications, visual, auditory, physical, and biological systems, to pure information that can then be reorganized into vast interactive networks that operate much like complex ecosystems. In other words, it is the interconnected nature of digitalization technology that allows us to penetrate borders and 'blur the lines between the physical, digital, and biological spheres'. Digitalization's modus operandi is 'interconnectivity and network building'. That's what digitalization has been doing, with increasing sophistication, for several decades. This is what defines the very architecture of the Third Industrial Revolution (Rifkin 2016).

Rifkin further rejected Schwab's speed-size-scope hypothesis. He showed that the intrinsic interconnectedness of networked information technologies and continuous exponential decrease in digital technology costs has continually produced changes in "velocity, scope, and systems impact" (2016) for some 35 years. Schwab's belief that this was a "new revolution" (2016) was a straightforward misconception.

In practical political terms, at Davos in 2016, Schwab needed neither Castells nor Rifkin in his move to shore up the flagging established global economic order. He skilfully avoided their influence, and that of other experts like them, in setting up the Davos 4IR frame.

However, despite the post-1976 echoes of the 4IR formula amongst the faithful, a careful historical analysis demonstrates that there is no such phenomenon as a 4IR in contemporary times. In the following section, I summarise a deeper and more systematic argument set out in Moll (2021a; 2021b).

\section{Why the 'Fourth Industrial Revolution' is a Myth}

Historians regard the First Industrial Revolution (1IR) as the archetypal industrial revolution. Historically, conceptually and methodologically, it provides criteria to determine whether any epoch or series of events can properly be considered to be an industrial revolution. The 1IR (circa 1760-1850) was a fundamental, transnational, socio-economic transformation, not just an emerging or merging of technologies. Hobsbawm (1962) describes it as both a successful and a tragic transition from an agricultural to an industrial economy - successful at the level of industrial development, and tragic in its human consequences. At its heart was the emergence of the British factory. The transatlantic convergence of machines - the cotton gin, the spinning mule, the mechanical loom and Watt's steam engine - radically increased the output of cotton textiles. Politically and economically, the 1IR marked the rise of capitalism and the demise of feudal society, and socially, it entailed the formation of the working class in conflict with an increasingly wealthy bourgeoisie (Hobsbawm 1962; Thompson 1963; Bythell 1983). Cotton, its primary raw commodity, was produced by slave labour (Beckert 2014; Dattel 2009), pivotal to early economic colonialism. The three-faced Janus of the IIR was the commodification of Africans, the brutalisation of slaves in the American colonies, and the immiseration of the working poor in Britain (Williams 1944/1994).

This historical complexity generates an analytic framework germane to any putative industrial revolution. For it to be recognised as such, the totality of the economic, social and political changes depicted in Figure 1 must be substantively realised. 
The ensemble of socioeconomic relations that constitute an industrial revolution

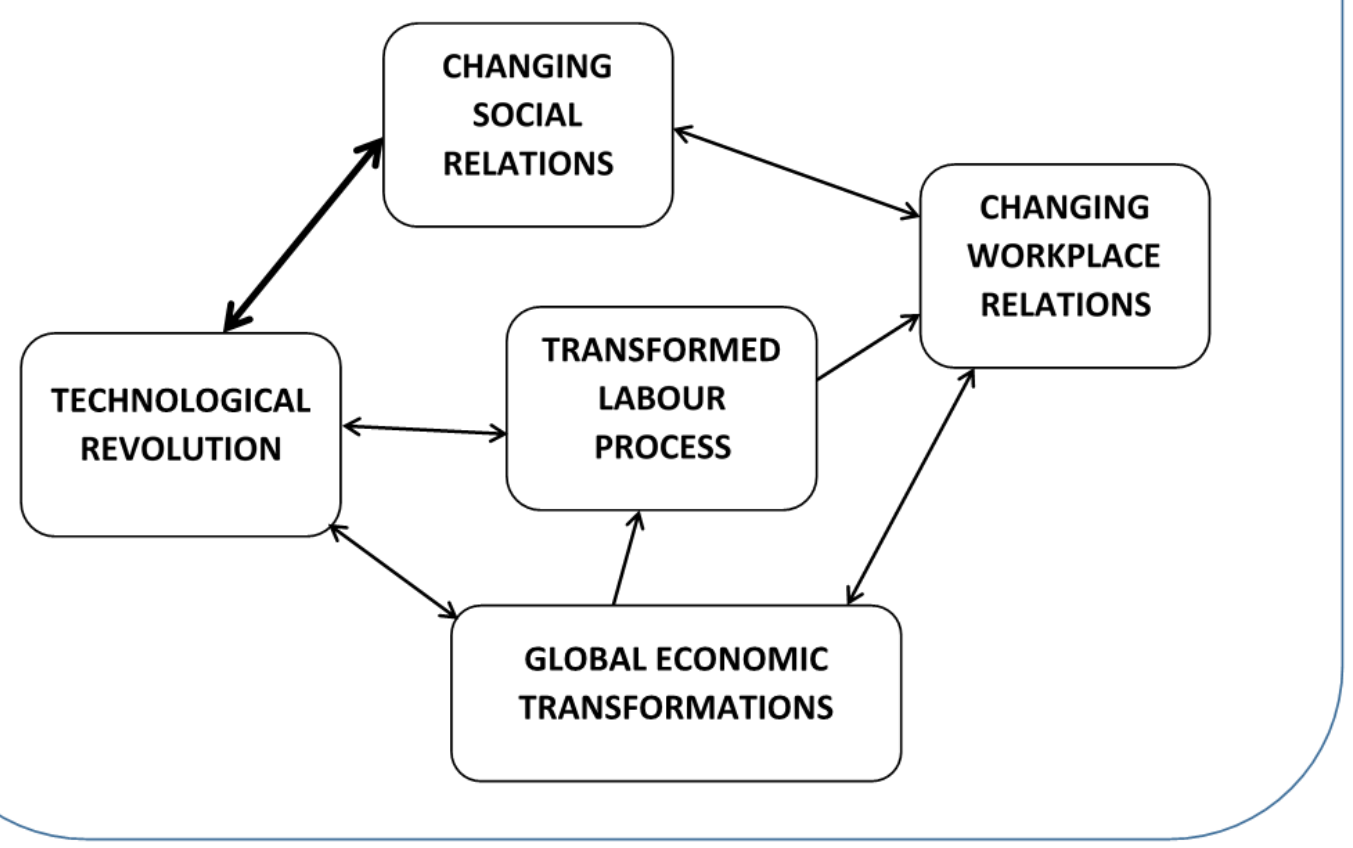

Figure 1: The socio-economic dimensions of an Industrial Revolution

Schwab's 4IR does not even meet the technological revolution criterion, let alone the others (Moll 2021a; 2021b). Examination of 'technologies' often proclaimed to be key converging innovations of the 4IR - artificial intelligence, machine learning, robotics, and the internet of things - indicates that they do not warrant the claim of a contemporary technological 'revolution':

a. Artificial Intelligence (AI), which is not technology per se, but a research field whose knowledge is applied in various technology fields, including software development and robotics, is very much of the 3IR, having commenced with the advent of high-speed digital computers in the 1950s.

b. Robots are computerised machines that replicate human action. From the development of the first industrial robot in 1961, robot technology progressed steadily. By 2000, there were some 750,000 industrial robots at work in factories across the world, and three million by 2021 (IFR 2021). Notably, the basic technology of this robotic working class has not changed much in the new millennium. Most robots on assembly lines are not 'intelligent', but from the eighties, robotics merged with machine learning to produce learning robots. Chatbots are ubiquitous today, but they evolved from natural language processing in the 1960s. 
c. Machine learning refers to the ability of computers to learn and make decisions as humans do, without programming. An 'artificial neural network' played checkers in the 1950s, and by 1997, a computer beat the world chess champion. A confluence of robotics and machine learning took shape from 1980 - by the nineties, robots that could "learn for themselves what is best for them" had been developed (Van de Velde 1993, 1). While the successes of 'deep learning' circa 2015 (such as facial recognition) are significant, the basics of 'convolutional neural networks' go back to the 1980s (LeCun et al. 2015).

d. An Internet of Things (loT) comprises networked mechanical and digital devices that transfer, process and act on data, without human intervention. The technology is not new - both the Internet and analogue/digital converters that enable loTs originate in the mid-1960s.

The obvious conclusion is that none of these supposed 4IR technologies is a groundbreaking invention of contemporary times. All of them are evolving technologies rooted in the defining technological transformations of the 3IR. Furthermore, there is no current, unprecedented, grand convergence of technologies that transcends the digital revolution in some way. Spiralling hype around 'converging 4IR technologies' clearly operates ideologically.

There are also no broader social transformations that indicate deep changes in work processes, labour relations, social life, and the global economy (Figure 1) that one would expect to find if this period was a 4IR. The "double-edged sword" of the 3IR - economic prosperity on one edge, and rising poverty, inequality and environmental degradation on the other - is relentless.

Automatised factory and office work that commenced in the 1980s continues to hollow out middle-class jobs in industrialised countries. In OECD countries, by 1995, over one-third of the labour force comprised temporary staff (Carnoy and Castells 2001). The proportion of mid-skill jobs has dropped from $42 \%$ in 2000 to $32 \%$ today. The OECD $(2019,3)$ predicts that employment in services will increase mostly in "lower-quality and precarious jobs".

In cities, suburban hierarchies based on class and race sustain urban planning approaches from the seventies (Castells 2000, xxxiii; Nijman and Wei 2020, 2). Disillusionment with the status quo continues to grow, with growing expressions of nationalism, fundamentalism and chauvinism, alongside multiplying identity politics, continuing on from the previous century.

Globally, the marginalisation and exploitation of the South endures. 'Multinational' corporations continue offshoring or outsourcing to reduce labour costs and maximise profit. All current evidence suggests these exploitative patterns will continue into the future (ILO 2019a). Many African nations, amongst the poorest in the world (Koop 2021), are forced to provide the cheapest labour to compete in the offshoring market (Barrett and Baumann-Pauly 2019).

The social context of the world is still that of the 3IR, and not much change is in sight. There is nothing like another industrial revolution taking place beyond the third, if you consider the five analytic criteria established earlier. Schwab's brave new world simply does not exist. 


\section{How 'Fourth Industrial Revolution' Ideology Works}

Nonetheless, the ideology continues to be recycled, persuading many that networked information technologies (modern 3IR technologies) have acquired powerful, new, convergent properties that can end inequality, joblessness and poverty. This proclamation of unprecedented technological convergence is considered to be the most socially significant element of the 4IR narrative (Morgan 2019, 374-375). Schwab speaks of "the staggering confluence of emerging technology breakthroughs" $(2016,7)$. A United Nations think-tank declares that the "conjunction of digital technologies and naturelike technologies [...] promise[s] unprecedented and previously unimaginable possibilities" (UNIDO 2019, 1). Marwala (2020) claims that "contrary to the earlier industrial revolutions, 4IR is based not on a single technology, but on the confluence of multiple, innovative technologies" (all my emphases). The role of these intellectuals seems to be to reformulate the ideological narrative of the networked 'free' market system as the gathering, transmission and use of data through operative combinations of technologies:

The doctrine of the information revolution [...] has become an indispensable ingredient in a massive reorganization of capitalist societies, centered on the introduction of new technologies. Formulated and promoted within the think tanks, policy institutes, laboratories, government offices, and consultancy circuits of the most powerful and prosperous centres of the capitalist world economy, the theory of an inevitable information revolution provides the rationale for this restructuring, legitimization for social dislocation, and exhortation toward a radiant future (Dyer-Witheford 1999, 37).

It is difficult to think of a better description of Schwab's intervention in 2016. He proclaims his "belief" in the 4IR frequently throughout the 2016 text, and each moment is an inflection point in his argument. The quasi-religious tone does not seem accidental. Gramsci wrote of the "religion of the intellectuals" to capture the sense in which an intellectual - in this case an organic intellectual of the ruling classes - articulates hegemonic ideology as a cognitively detailed interpretive system that echoes in the thought and behaviour of ordinary people (Gramsci 1971, 325-326).

The truth is that this ideological framing of an ICT-driven global economy reifies and obscures contemporary neoliberal politics. Sutherland suggests that "the 4IR is an attractive flag around which to spin an elitist and neoliberal vision of the future of manufacturing" $(2020,246)$ - the WEF's task is to convince governments to invest in new technologies and manufacturing systems. The WEF must also assist in mitigating damaging socio-economic effects in order to shore up the ailing world economy.

\section{Neoliberalism and its Ideologies}

Neoliberalism is a policy model based on transferring control of the economy from the public sector to the private sector. It emphasises free-market capitalism and limits on state regulation and spending. Harvey describes it as a doctrine that "the social good will be maximized by maximizing the reach and frequency of market transactions" $(2005,3)$. It is closely associated with socio-economic globalisation. In the 1980s, the 'Washington consensus' established a global 'free trade' regime that integrated markets and resource allocation. Nation states were reorganised to facilitate international competition. The World Bank and other 'supranational states' - the core of a "de facto world government" (Chomsky 1999, 20) - became notorious for imposing this regime through 'structural adjustment' programmes. 
From the 1970s, there was a deep, historical, structural relationship between globalisation, neoliberal ideology and the proliferation of networked ICTs. Castells' major theoretical contribution has been to understand these mutually generative ideologies and practices as they constitute the 3IR. Harvey's view is that they bias technological changes "away from production and infrastructure formation [...towards] market-driven financialization [...and so i]nformation technology is the privileged technology of neoliberalism" (Harvey 2005, 157-158).

Some authors argue that this close embrace between neoliberalism and ICTs is historically contingent (Arrighi 1994; Pellizzoni and Ylönen 2012), that "the digital revolution has the misfortune of unfolding in a neo-liberal era" (Kozul-Wright 2018). The very idea of a confluence of technologies seems to imply that technologies will be contingent. However, my view is that this sense of an accidental historical encounter puts the case too strongly - Castells' empirical evidence of an identity between the ICTdriven global economy and neoliberal ideology demonstrates more than just historical contingency. In all three industrial revolutions, a confluence of technologies was necessary.

Going back to the assertions of Schwab, UNIDO and Marwala that the 4IR is somehow unique in this regard, it is clear that they are profoundly misleading: the revolutionary technological aspect of the 1IR was the transatlantic convergence of spinning and weaving machines and Watt's steam engine. The systematically planned convergence of technologies was essential to the assembly lines of the Second Industrial Revolution (2IR) factory (Jevons 1931). In the 3IR, the Internet is the technology of the convergence of technologies that enables the fusion of multiple digitised technologies. The claims about 4IR convergences are apparently the work of organic intellectuals doing their jobs - they "could provide illustrations that proliferate to cover virtually any activity within society" (Morgan 2019, 374).

In his recent analysis of neoliberalism, Castells (2018) recognises the rupturing logic of global networks, capital and people. This is what the technology convergence metaphors elide - "the profound movement of mass rebellion against the established order in the contemporary world" (36-37). He points to the irony that, in recent times, the more people get connected to the Internet, the less they are able to access the power-exercising nodes of the Net (the globalised networks of power in information society). This generates social movements that, following digitalised network logics, are able to challenge the apparatuses of institutional power. There is a sense in which connections between globalisation and neoliberalism on the one hand, and globally networked information systems on the other, are starting to unravel, to become more contingent, as it were.

Since the early 2000 s, neoliberalism has faced mounting crises. Stiglitz (2015) laments the distrust of the market, elites and (economic) science produced by the "grand deception" of neoliberalism over 40 years, namely that economic prosperity "trickles down" to the poor. He condemns the "lie" that economic prosperity requires workers to settle for lower wages (Stiglitz 2019b). In similar vein, Harvey suggests that the "main substantive achievement of neoliberalization [...] has been to redistribute, rather than to generate, wealth and income" $(2005,158)$.

The global meltdown of 2008-2009 and the current Covid-19 pandemic are two in a series of crises faced by the dominant free-market ideology. For Stiglitz (2019a), "neoliberalism must be pronounced dead and buried". However, contemporary economic debate is less adamant about this (Aalbers 2013; Mirowski 2014; Davies 2016; Ostry, Loungani and Furceri 2016), despite praise for Stiglitz's analyses of neoliberal 
decline. It seems clear that the WEF intervention in 2016 is one way in which "neoliberal practice is able to resurface and show up in [...] new and unexpected ways" (Aalbers 2013, 1083).

\section{The Future of Work}

Nowhere is this clearer than in the ideology that the 4IR promises a net gain of new jobs arising from the automation of work. The 2018 WEF Future of Jobs Report forecasts 75 million job losses, but reassures us that changing workplace relations between humans and machines will create 133 million new human jobs: a net gain of 58 million (WEF 2018, viii). Such predictions, says Gillwald (2019), "packaged with futurist conviction and fantastical economic forecasts of exponential growth and job creation [...] appear to provide a ready roadmap in an uncertain future". In his 2016 intervention, Schwab was careful not to make such overblown claims: so too was the 2016 Future of Jobs Report (WEF 2016). For example, Schwab cautions:

The fundamental uncertainty has to do with the extent to which automation will substitute for labour [...] There are [...] those who believe [...] workers displaced by technology will find new jobs, and [...] technology will unleash a new era of prosperity; and those who believe it will lead to [...] technological unemployment on a massive scale. History shows that the outcome is likely to be somewhere in the middle (2016, 37-38).

However, by 2018 and 2019, this caution seems to have been swept away with talk in WEF forums of substantial job creation: "Al and robotics will ultimately create more work, not less. [...] There won't be a shortage of jobs but - if we don't take the right steps - a shortage of skilled talent to fill those jobs" (Kasriel 2019).

These triumphal claims are difficult to make sense of when read in conjunction with International Labour Organization (ILO) employment statistics (or those published by the OECD and World Bank). These statistics reveal consistent decline in stable employment after the 2015 global economic crisis, partially explained by ongoing technology adoption in workplaces. By 2016, 197 million people could not find jobs, 27 million higher than pre-crisis levels (ILO 2016, 3). 2017 saw an unemployment increase of 3.4 million, bringing the total to over 201 million, as "the pace of labour force growth outstrip[ped] job creation" (ILO 2017, 6). In 2018, global unemployment figures stabilised. However, manufacturing employment declined overall as a result of the automation of work and "premature deindustrialization" (ILO 2018). Increasing numbers of people were now being pushed into precarious employment (or 'subemployment') in the service sector - the ILO characterises such work as "a shortage of decent jobs" (2016, $19 ; 2019 b, 31)$. Approaching 2018, $50 \%$ of the employed in "emerging countries" and $80 \%$ in "developing countries" had vulnerable jobs of this kind (ILO 2017). By 2019, roughly 2 billion out of the 3.3 billion globally employed (61\%) were working informally, and "experienced a lack of material well-being and economic security" (ILO 2019b, 1). Bluntly put, despite having jobs, they lived in poverty. This was all before Covid-19, although in 2020 the pandemic brought unprecedented global employment losses of 114 million jobs (ILO 2021, 2).

The deepening global 'subemployment' crisis is not all down to Covid-19. Structural features of revivalist neoliberalism are at work too. Jones (2021) shows that, from the 19th century until recently, most people in the world relied on a wage. In the current "gig economy", stable middle-class jobs and therefore stable wages are waning. It is a 
function of the global digitalised economy that increasing numbers of people find themselves in "the region between employment and unemployment - waged and wageless life - that has blossomed amid the ruins of industrial growth" (Jones 2021, 25). Furthermore, countries in the Global South tend to be further marginalised, also only partially as a consequence of the international isolation of the pandemic. Whether by onshoring back to automated factories, or 'back home' outsourcing to 'the cloud', employment is increasingly confined to elites (Jones 2021, 28; Moll 2021a, 28; Studley 2021). Both at the core and on the peripheries of globalised capitalism, job losses multiply.

The reason for the discrepancy between the upbeat WEF view on jobs and the cold, hard statistics of the ILO becomes clear after some digging into the methodology of the WEF reports, hidden away in appendices. If the intention was to produce generalised reports on the global 'future of jobs', then the WEF's research samples have in each case been systematically distorted and are unrepresentative. Its researchers interviewed senior corporate managers about optimistic, idealised, projected future employment wish-lists in their own companies, and projected their coding of this data as general, universally valid conclusions on the 'future of jobs'. The conclusion seems inescapable that these reports, too, function ideologically to obscure ongoing job losses, the decline of the middle classes, and the erosion of decent work in the global digital economy. Neoliberalism is attempting to reshape itself ideologically.

\section{Resistance to the 'Fourth Industrial Revolution' Ideology}

Earlier I stressed the humanist theorisation of ideology across psychological, political and cultural strata by Lakoff, Gramsci and the Frankfurt School respectively. All these theorists have strong theoretical and activist orientations to overcoming ideological domination. Gramsci's view of the possibility and necessity of counter-hegemonic struggle is well known. Critics forget that Lakoff's terrain is cultural linguistics, in which articulated language constantly changes in political contestations, and so must be neurologically instantiated in new forms from time to time. His political work exposing the dominant metaphorical frames of Trumpism is testimony to the ideological contestation inherent in his work (Lakoff 2016). Finally, in the Frankfurt School itself, there are strong commitments in the notion of ideologiekritik to cultural and ideological struggle against domination - e.g. Erich Fromm's (1961) critique of Althusser's 'falsification of Marxism", and indeed Marcuse's later works (1969; 1972).

Although it is not within the scope of this article to explore, in detail, struggles against the notion of the 4IR, it should be noted that the ongoing crisis of neoliberalism presents opportunities for counter-hegemonic globalisation - the "growth of transnational connections [that] can potentially be harnessed to the construction of more equitable distributions of wealth and power" (Evans 2019, 550). There is a strong tradition of 'anti-globalisation' activism in the World Social Forum (WSF), inter alia at and around the annual Davos gatherings. The WSF was in fact established to oppose the WEF, particularly its neoliberalism, and "imperialism in all its forms" (Wallerstein 2004, 629). In this tradition, Naomi Klein regards each of the WEF's "big themes" in a similar fashion, describing the $20164 \mathrm{IR}$ theme as follows :

[It is not] a serious effort to actually solve the crises it describes. On the contrary, it is an attempt to create a plausible impression that the huge winners in this system are on the verge of voluntarily setting greed aside to get serious about solving the raging crises that are radically destabilizing our world. Because if our corporate overlords can create this impression, it is less likely that governments will listen to the rising chorus of voices calling on them to do what is 
required to actually combat spiraling poverty, joblessness, climate breakdown, and informational degeneration (Klein 2020).

Not all the literature nor all the activism that is emerging takes as strong a view as does Klein. However, there are clear indications that the apparently massive 4IR may rupture in the face of current crises, and that this may lead to increased counter-hegemonic use of ICTs in future. As Gramsci might say, the site of struggle is not the 4IR; it is the deepening, crisis-ridden 3IR in which 4IR ideology plays itself out.

\section{Conclusion}

The ideological construal of a 4IR completely fails to grasp the complexity and import of what an industrial revolution actually is. It reduces the idea of 'revolution' to technological innovation, and deflects attention away from the marginalisation of what is now fast becoming a majority of the world's people. Under the sway of 4IR ideology, people conceive of social change as produced by technological progress, not social and political will. As Marcuse puts it, "technological rationality reveals its political character as it becomes the great vehicle of better domination, creating a truly totalitarian universe in which society and nature, mind and body are kept in a state of permanent mobilization for the defense of this universe" $(1964,18)$.

This article suggests that the ideology of the 4IR functions to position, indeed continuously reposition, a close association of neoliberalism and networked ICTs in the interests of the ruling elites of the world. The reality is continuing globalisation, and "tensions between those who drive it and benefit from it, and those who are marginalised by it and often resist it" (Moll 2021a, 29). In the hands of the WEF, 4IR talk encourages social practices that favour a capitalism that "denies work to the many", rather than one that "encompasses change that may liberate the many from work" (Morgan 2019, 371).

The ideologues - the organic intellectuals - of the 4IR continue to convince most people that a massive consolidation of networked technologies is in their own best interests. This despite all the evidence that more and more people are losing jobs, economic stability, prosperity, decent work, and respect for their humanity and diversity. Marwala gives us a rare glimpse of this when he momentarily lifts the veil of ideology:

[T] hose who master the means and ways of the 4IR shall thrive. Those who fail to master this revolution shall be thrown into the dustbin of backwardness. (Tshilidzi Marwala, quoted in Wits University 2018)

As he casts out those whom he regards as backward, I wonder if he understands that this includes not just the "other half" (George 1976) of the world's population that has long been marginalised by global elites, but also many among that half of humanity who did have relatively stable jobs and some prosperity in the relatively recent past?

\section{References}

Aalbers, Manuel. 2013. Neoliberalism is Dead... Long Live Neoliberalism! International Journal of Urban and Regional Research 37 (3): 1083-1090. doi:10.1111/1468-2427.12065

Althusser, Louis. 1971. Lenin and Philosophy and Other Essays. New York: Monthly Review Press.

Althusser, Louis. 1969. For Marx. New York: Pantheon.

Arrighi, Giovanni. 1994. The Long Twentieth Century. London: Verso. 
Barrett, Paul and Dorothée Baumann-Pauly. 2019. Made in Ethiopia: Challenges in the Garment Industry's New Frontier [report]. New York University: Stern Centre for Business and Human Rights. Accessed February 1, 2022. https://humanrights.wbcsd.org/project/madein-ethiopia-challenges-in-the-garment-industrys-new-frontier/

Beckert, Sven. 2014. Empire of Cotton: A Global History. New York: Alfred A. Knopf.

Benyera, Ernesto. 2021. The Fourth Industrial Revolution and the Recolonisation of Africa: The Coloniality of Data. London: Routledge.

Bilić, Paško. 2018. A Critique of the Political Economy of Algorithms: A Brief History of Google's Technological Rationality. triple C: Communication, Capitalism and Critique 16 (1): 315-331. doi:10.31269/vol16iss1pp315-331

Bythell, Duncan. 1983. Cottage Industry and the Factory System. History Today 33 (4): 1723.

Carnoy, Martin and Manuel Castells. 2001. Globalization, the Knowledge Society, and the Network State: Poulantzas at the Millennium. Global Networks 1 (1): 1-18. doi:10.1111/1471-0374.00002

Castells, Manuel. 2018. Rupture: The Crisis of Liberal Democracy. Cambridge: Polity Press.

Castells, Manuel. 2004. Network Society: A Cross-Cultural Perspective. London: Edward Elgar.

Castells, Manuel. 2000. The Rise of the Network Society. Chichester: Wiley Blackwell.

Castells, Manuel. 1999. Information Technology, Globalization and Social Development. Discussion Paper No. 114. Geneva: United Nations Research Institute for Social Development.

Chomsky, Noam. 1999. Profit Over People: Neoliberalism and the World Order. New York: Seven Stories.

Davies, Will. 2016. The Limits of Neoliberalism: Authority, Sovereignty and the Logic of Competition. London: Sage.

Dattel, Eugene. 2009. Cotton and Race in America (1787-1930): The Human Price of Economic Growth. Chicago: Ivan Dee.

Delanty, Gerard and Neal Harris. 2021. Critical Theory and the Question of Technology: The Frankfurt School revisited. Thesis Eleven 166 (1): 88-108. doi:10.1177/07255136211002055

Dyer-Witheford, Nick. 1999. Cyber-Marx. Cycles and Circuits of Struggle in High-Technology Capitalism. Chicago: University of Illinois Press.

Evans, Peter. 2019. Counterhegemonic Globalization: Transnational Social Movements in the Contemporary Political Economy. In Frank Lechner and John Boli (eds.), The Globalization Reader, 550-556. Oxford: Wiley Blackwell.

Fromm, Erich. 1961. Marx's Concept of Man. New York: Frederick Ungar Publishing.

Fuchs, Christian. 2018. Industry 4.0: The Digital German Ideology. tripleC: Communication, Capitalism and Critique 16 (1): 280-289. doi:10.31269/triplec.v16i1.1010

George, Susan. 1976. How the Other Half Dies: The Real Reasons for World Hunger. Harmondsworth: Penguin.

Gillwald, Alison. 2019. South Africa is Caught in the Global Hype of the Fourth Industrial Revolution. The Conversation, August 20. Accessed February 6, 2022. https://theconversation.com/south-africa-is-caught-in-the-global-hype-of-the-fourth-industrial-revolution$\underline{121189}$

Gramsci, Antonio. 1971. Selections from the Prison Notebooks of Antonio Gramsci. New York: International Publishers.

Hall, Stuart. 1980. Race, Articulation and Societies Structured in Dominance. In UNESCO (ed.). Sociological Theories: Race and Colonialism, 305-345. Paris: United Nations Educational, Scientific and Cultural Organisation.

Harvey, David. 2005. A Brief History of Neoliberalism. Oxford: Oxford University Press. 
Harvey, Ross. 2017. The 'Fourth Industrial Revolution': Potential and Risks for Africa. The Conversation, 30 March. https://theconversation.com/the-fourth-industrial-revolution-potential-and-risks-for-africa-75313

Hobsbawm, Eric. 1962. The Age of Revolution: Europe 1789-1848. London: Weidenfeld and Nicolson.

Horkheimer, Max and Theodor Adorno. 1944/2002. The Culture Industry: Enlightenment as Mass Deception. In Dialectic of Enlightenment. Philosophical Fragments. 94-136. Stanford CA: Stanford University Press.

IFR (International Federation of Robotics). 2021. IFR Presents World Robotics Report 2021. Press release, October 28, Frankfurt. Accessed February 1, 2022. https://ifr.org/ifr-pressreleases/news/robot-sales-rise-again

ILO (International Labour Organization). 2021. ILO Monitor: COVID-19 and the World of Work. January 25. Accessed February 1, 2022. https://www.ilo.org/wcmsp5/groups/public/@dgreports/@dcomm/documents/briefingnote/wcms 767028.pdf

ILO 2019a. The Future of Work in Textiles, Clothing, Leather and Footwear. Working Paper No. 326. Geneva: ILO Sectoral Policies Department.

ILO 2019b. World Employment Social Outlook: Trends 2019. Geneva: ILO.

ILO 2018. World Employment Social Outlook: Trends 2018. Geneva: ILO.

ILO 2017. World Employment Social Outlook: Trends 2017. Geneva: ILO.

ILO 2016. World Employment Social Outlook: Trends 2016. Geneva: ILO.

Jevons, Stanley. 1931. The Second Industrial Revolution. The Economic Journal 41 (161): 1-18. doi:10.2307/2224131

Jones, Phil. 2021. Work Without the Worker: Labour in the Age of Platform Capitalism. London: Verso.

Kasriel, Stephane. 2019. What the next 20 years will mean for jobs - and how to prepare. World Economic Forum Annual Meeting, Davos, Switzerland, 22-25 January. Accessed February 2, 2022. https://www.weforum.org/agenda/2019/01/jobs-of-next-20-years-howto-prepare/

Kayembe, Christian and Danielle Nel. 2019. Challenges and Opportunities for Education in the Fourth Industrial Revolution. African Journal of Public Affairs 11 (3): 79-94.

Klein, Naomi. 2020. The Great Reset Conspiracy Smoothie. The Intercept, 8 December. Accessed February 1, 2022. https://theintercept.com/2020/12/08/great-reset-conspiracy/

Koop, Avery. 2021. Mapped: The 25 Poorest Countries in the World. Visual Capitalist. Accessed February 2, 2022. https://www.visualcapitalist.com/

Kozul-Wright, Richard. 2018. Neoliberalism has captured the digital revolution. El País: El Periódico Global, October 30. Accessed February 6, 2022. https://english.elpais.com/elpais/2018/10/30/inenglish/1540909557 656379.html

Lakoff, George. 2016. Understanding Trump. George Lakoff [Blog], June 23. Accessed February 2, 2022. https://georgelakoff.com/2016/07/23/understanding-trump-2/

Lakoff, George. 2008. The Political Mind: A Cognitive Scientist's Guide to Your Brain and its Politics. New York: Penguin.

Lakoff, George and Mark Johnson. 1999. Philosophy in the Flesh: The Embodied Mind and its Challenge to Western Thought. New York: Basic Books.

Lakoff, George and Mark Johnson. 1980. Metaphors We Live By. Chicago: University of Chicago Press.

LeCun, Yan, Yoshua Bengio and Geoffrey Hinton. 2015. Deep Learning. Nature 521, 436444. doi:10.1038/nature14539

Marcuse, Herbert. 1972. Counterrevolution and Revolt. Boston: Beacon Press.

Marcuse, Herbert. 1969. An Essay on Liberation. Boston: Beacon Press.

Marcuse, Herbert. 1964. One-Dimensional Man: Studies in the Ideology of Advanced Industrial Society. Boston: Beacon Press. 
Marwala, Tshilidzi. 2020. Covid-19 Has Forced Us into the Fast Lane of the 4IR Super-Highway. Daily Maverick, May 28. Accessed February 2, 2022. https://www.dailymaverick.co.za/opinionista/2020-05-28-covid-19-has-forced-us-into-the-fast-lane-of-the-4ir-super-highway/

Marx, Karl. 1859/1977. A Contribution to the Critique of Political Economy. Marx/Engels Internet Archive. https://www.marxists.org/archive/marx/works/1859/critique-pol-economy/preface.htm

Mirowski, Phillip. 2014. How Neoliberalism Survived the Financial Meltdown. London: Verso.

Moll, Ian. 2021a. The myth of the fourth industrial revolution. Theoria: A Journal of Social and Political Theory 68 (167): 1-38. doi:10.3167/th.2021.6816701

Moll, Ian. 2021b. The Myth of the Fourth Industrial Revolution: Implications for Teacher Education. In Felix Maringe (ed.), Higher Education in the Melting Pot: Emerging Discourses of the 4IR and Decolonisation. 91-110. Cape Town: Aosis.

Morgan, Jamie. 2019. Will We Work in Twenty-First Century Capitalism? A Critique of the Fourth Industrial Revolution Literature. Economy and Society 48 (3): 371-398. doi:10.1080/03085147.2019.1620027

Neubauer, Robert. 2011. Neoliberalism in the Information Age, or Vice Versa? Global citizenship, technology, and hegemonic ideology. triple C: Communication, Capitalism and Critique 9 (2): 195-230. doi:10.31269/triplec.v9i2.238

Nijman, Jan and Yehua Wei. 2020. Urban Inequalities in the 21st Century Economy. Applied Geography 117: 1-8. doi:10.1016/j.apgeog.2020.102188.

OECD (Organisation for Economic Co-operation and Development). 2019. OECD Employment Outlook 2019: The Future of Work. Paris: OECD Publishing.

Ostry, Jonathan, Prakash Loungani and Davide Furceri. 2016. Neoliberalism: Oversold? Finance and Development (June): 38-41. International Monetary Fund. Accessed February 2, 2022. https://www.imf.org/external/pubs/ft/fandd/2016/06/pdf/ostry.pdf

Pellizzoni, Luigi and Marja Ylönen (eds). 2012. Introduction. In Neoliberalism and Technoscience: Critical Assessments, 1-26. Farnham: Ashgate Publishing.

Peters, Michael. 2017. Technological Unemployment: Educating for The Fourth Industrial Revolution. Educational Philosophy and Theory 49 (1): 1-6. doi:10.1080/00131857.2016.1177412

Reischauer, Georg. 2018. Industry 4.0 as Policy-Driven Discourse to Institutionalize Innovation Systems in Manufacturing. Technological Forecasting and Social Change 132: 26-33. doi:10.1016/j.techfore.2018.02.012

Rifkin, Jeremy. 2016. The 2016 World Economic Forum Misfires with Its Fourth Industrial Revolution Theme. Industry Week, January 16.

Rifkin, Jeremy. 2014. The Zero Marginal Cost Society: The Internet of Things, the Collaborative Commons, and the Eclipse of Capitalism. New York: St. Martin's Press.

Rifkin, Jeremy. 2011. The Third Industrial Revolution: How Lateral Power Is Transforming Energy, The Economy, and the World. New York: Palgrave MacMillan.

Rifkin, Jeremy. 1995. The End of Work: The Decline of the Global Labor Force and the Dawn of The Post-Market Era. New York: Putnam.

Salamini, Leonardo. 1974. Gramsci and Marxist Sociology of Knowledge: An Analysis of Hegemony-Ideology-Knowledge. Sociological Quarterly 15 (3): 359-380. doi:10.1111/j.15338525.1974.tb00900.x

Schwab, Klaus. 2016. The Fourth Industrial Revolution. Geneva: World Economic Forum.

Soper, Kate. 1986. Humanism and Anti-Humanism. London: Hutchinson.

Stiglitz, Joseph. 2019a. After Neoliberalism. Project Syndicate, May 30. Accessed February 2, 2022. https://www.project-syndicate.org/commentary/after-neoliberalism-progressivecapitalism-by-joseph-e-stiglitz-2019-05

Stiglitz, Joseph. 2019b. The End of Neoliberalism and the Rebirth of History. Social Europe, November 26. Accessed February 2, 2022. https://socialeurope.eu/the-end-of-neoliberalism-and-the-rebirth-of-history 
Stiglitz, Joseph. 2015. The Great Divide: Unequal Societies and What We Can Do About Them. New York: Norton.

Studley, Matthew. 2021. Onshoring Through Automation: Perpetuating Inequality? Frontiers in Robotics and Al, 17 June. doi:10.3389/frobt.2021.634297

Sutherland, Ewan. 2020. The Fourth Industrial Revolution - The Case of South Africa. Politikon 47 (2), 233-252. doi:10.1080/02589346.2019.1696003

Thompson, E.P. 1978. The Poverty of Theory and Other Essays. New York: Monthly Review Press.

Thompson, E.P. 1963. The Making of the English Working Class. London: Victor Gollancz.

UNIDO (United Nations Industrial Development Organization). 2019. Nature-like and Convergent Technologies Driving the Fourth Industrial Revolution [report]. Vienna: UNIDO.

Van de Velde, Walter, ed. 1993. Toward Learning Robots. Cambridge, MA: MIT Press.

Wallerstein, Immanuel. 2004. The dilemmas of open space: the future of the WSF. International Social Science Journal 56 (182): 629-637. doi:10.1111/j.0020-8701.2004.00522.x

WEF. 2021. The Davos Agenda. Accessed February 2, 2022. https://www.weforum.org/events/the-davos-agenda-2021.

WEF. 2018. The Future of Jobs Report 2018. Geneva: World Economic Forum.

WEF. 2016. The Future of Jobs Report 2016. Geneva: World Economic Forum.

Williams, Eric. 1944/1994. Capitalism and Slavery. Chapel Hill, NC: University of North Carolina Press.

Wits University. 2018. \#SA4IR to Explore How The 4th Industrial Revolution Could Shape SA. September 5. Accessed February 2, 2022. https://www.wits.ac.za/news/latestnews/research-news/2018/2018-09/sa4ir-to-explore-how-the-4th-industrial-revolutioncould-shape-sa.html

Zuboff, Shoshana. 2019. The Age of Surveillance Capitalism: The Fight for a Human Future at the New Frontier of Power. New York: Public Affairs.

\section{About the Author}

lan Moll

lan Moll is a research fellow in the Centre for Researching Education and Labour (REAL) at the University of the Witwatersrand, Johannesburg, South Africa. He was retired as an academic member of the Division of Educational Information and Engineering Technology of the same university at the end of 2021 . His interests lie in the networked society, theoretical psychology, learning and pedagogy, and e-learning. His $\mathrm{PhD}$ is in cognitive science and education from the University of Geneva. During his career, he has been a junior primary teacher, an adult literacy teacher, a trade unionist, a District Director in the Gauteng Department of Education, a researcher at the South African Institute for Distance Education, visiting professor at the Universities of Makarere and Witwatersrand (where he was a lead researcher in the Panafrican Agenda on the Pedagogic Integration of ICTs), and lecturer in educational theory, psychology of education and online instructional design. 